\title{
Enzyme Uncoupling
}

National Cancer Institute

\section{Source}

National Cancer Institute. Enzyme Uncoupling. NCI Thesaurus. Code C40500.

Through physical or functional dissociation, Enzyme Uncoupling involves alteration

(typically disruption) of activity of a physically or functionally coordinated biological complex that possesses catalytic activity. 